\title{
Rodent-borne viruses survey in rural settlers from Central Brazil
}

\author{
Jorlan Fernandes ${ }^{1}$, Renata Carvalho de Oliveira', Thayssa Alves Coelho', \\ Regina Maria Bringel Martins ${ }^{2}$, Karlla Antonieta Amorim Caetano ${ }^{3}$, \\ Marco Aurélio Pereira Horta ${ }^{4}$, Silvana Levis ${ }^{5}$, Megmar Aparecida dos Santos Carneiro², \\ Sheila A Teles ${ }^{3}$, Elba Regina Sampaio de Lemos ${ }^{1 /+}$
}

'Fundação Oswaldo Cruz-Fiocruz, Instituto Oswaldo Cruz, Laboratório de Hantaviroses e Rickettsioses, Rio de Janeiro, RJ, Brasil ${ }^{2}$ Universidade Federal de Goiás, Instituto de Patologia Tropical e Saúde Pública, Goiânia, GO, Brasil

${ }^{3}$ Universidade Federal de Goiás, Faculdade de Enfermagem, Goiânia, GO, Brasil

${ }^{4}$ Fundação Oswaldo Cruz-Fiocruz, Instituto Oswaldo Cruz, Rio de Janeiro, RJ, Brasil

${ }^{5}$ Instituto Nacional de Enfermedades Virales Humanas, Pergamino, Argentina

Anthropogenic environmental changes arising from settlement and agriculture include deforestation and replacement of natural vegetation by crops providing opportunities for pathogen spillover from animals to humans. This study aimed to investigate the prevalence of rodent-borne virus infections in seven rural settlements from Midwestern Brazil. Of the 466 individuals tested $12(2.57 \%)$ were reactive for orthohantavirus and $3(0.64 \%)$ for mammarenavirus. These rural settlers lived under unfavorable infrastructure, socioeconomic disadvantages, and unsanitary conditions, representing a risk for rodent-borne infections. Development of public policies towards the improvement of health, sanitation and awareness of rodent-borne diseases in improvised camps and settlements is imperative, in order to reduce morbidity and mortality caused by these diseases.

Key words: hantavirus - arenavirus - rural settlers - rodent-borne diseases

Human behavior, especially spatial expansion of agriculture, has been implicated as drivers of some recent emerging disease events that had important impact on human health. ${ }^{(1)}$ Anthropogenic environmental changes caused by settlement and agriculture include habitat deforestation, fragmentation, and replacement of natural vegetation by crop fields. ${ }^{(2)}$ These changes modify wildlife population structure and migration and reduce biodiversity by creating environments that favor particular hosts, vectors, and/or pathogens. ${ }^{(1,2)}$

Rural settlers are a growing population in Brazil, where currently 9,256 rural settlements are listed, occupying an area of $88,314,857$ hectares (three times the size of the United Kingdom). ${ }^{(3)}$ These settlements were established to encourage landless rural workers on unproductive properties to be relocate to potentially productive areas through a system of land grants. Often, before they own the land, they live in camps, where living conditions are unfavorable. ${ }^{(4)}$ In addition, many families live in rudimentary housing, devoid of piped water, electricity, selective garbage collection, conditions that favors proliferation and increases chances of contact with rodents. ${ }^{(4,5,6)}$ In this context of social vulnerability and environmental degradation, this study aimed to investigate the prevalence of rodent-borne viruses (hantaviruses and mammarenaviruses) infections in rural settlers from Brazil.

doi: 10.1590/0074-02760180448

Financial support: FIOCRUZ, CAPES, FAPEG, CNPq (grant no 404762/2016-6), Universidade Federal de Goiás.

+ Corresponding author: elba.lemos@ioc.fiocruz.br

Received 24 September 2018

Accepted 27 November 2018
Human infections caused by hantaviruses and mammarenaviruses are associated with the natural cycle of these viruses, and transmission usually occurs by inhalation of aerosolised rodent excreta. ${ }^{(7)}$ Brazil occupies most of the eastern portion of South America, supporting several biomes with multiple natural ecosystems that account for the reported regional differences and temporal trends of hantavirus pulmonary syndrome (HPS). ${ }^{(8)}$ To date, more than 2,000 HPS cases have been reported and six hantavirus genotypes have been identified as pathogenic to humans in Brazil: Juquitiba, Araraquara, Castelo dos Sonhos, Laguna Negra, Anajatuba and Rio Mamore viruses. These viruses are transmitted by wild rodent reservoirs of the species Oligoryzomys nigripes, Necromys lasiurus, Oligoryzomys utiaritensis, Calomys callidus, Oligoryzomys mattogrossae and Oligoryzomys microtis, respectively. ${ }^{(7,8)}$ In contrast, only one case of Brazilian haemorrhagic fever was described in 1990, which was caused by Sabiá mammarenavirus, for which the animal reservoir is still unknown. ${ }^{(9)}$

A cross-sectional study was conducted in rural settlements from southwest of Goiás state, Central Brazil. Individuals from seven rural settlement projects established in Perolândia (Lagoa do Bonfim and Três Pontes) and Jataí (Santa Rita, Rio Claro, Nossa Senhora de Guadalupe, Terra e Liberdade and Gurita) counties (Figure) were interviewed using a standard questionnaire to record their sociodemographic and behavioral characteristics, as reported previously. ${ }^{(4,5)}$ Blood was collected $(10 \mathrm{~mL})$ from all participants, and serum samples were tested by an enzyme-linked immunosorbent assay (ELISA) for the detection of anti-hantavirus and mammarenavirus immunoglobulin $\mathrm{G}(\mathrm{IgG}){ }^{(10,11)}$ This study was aproved by the Research and Ethics Committee of Hospital das Clínicas, Universidade Federal de Goiás number 127/2010, and by Fundação Oswaldo Cruz/Instituto Oswaldo Cruz Ethical Committee, number CAAE 61629416.2.1001.5248. 


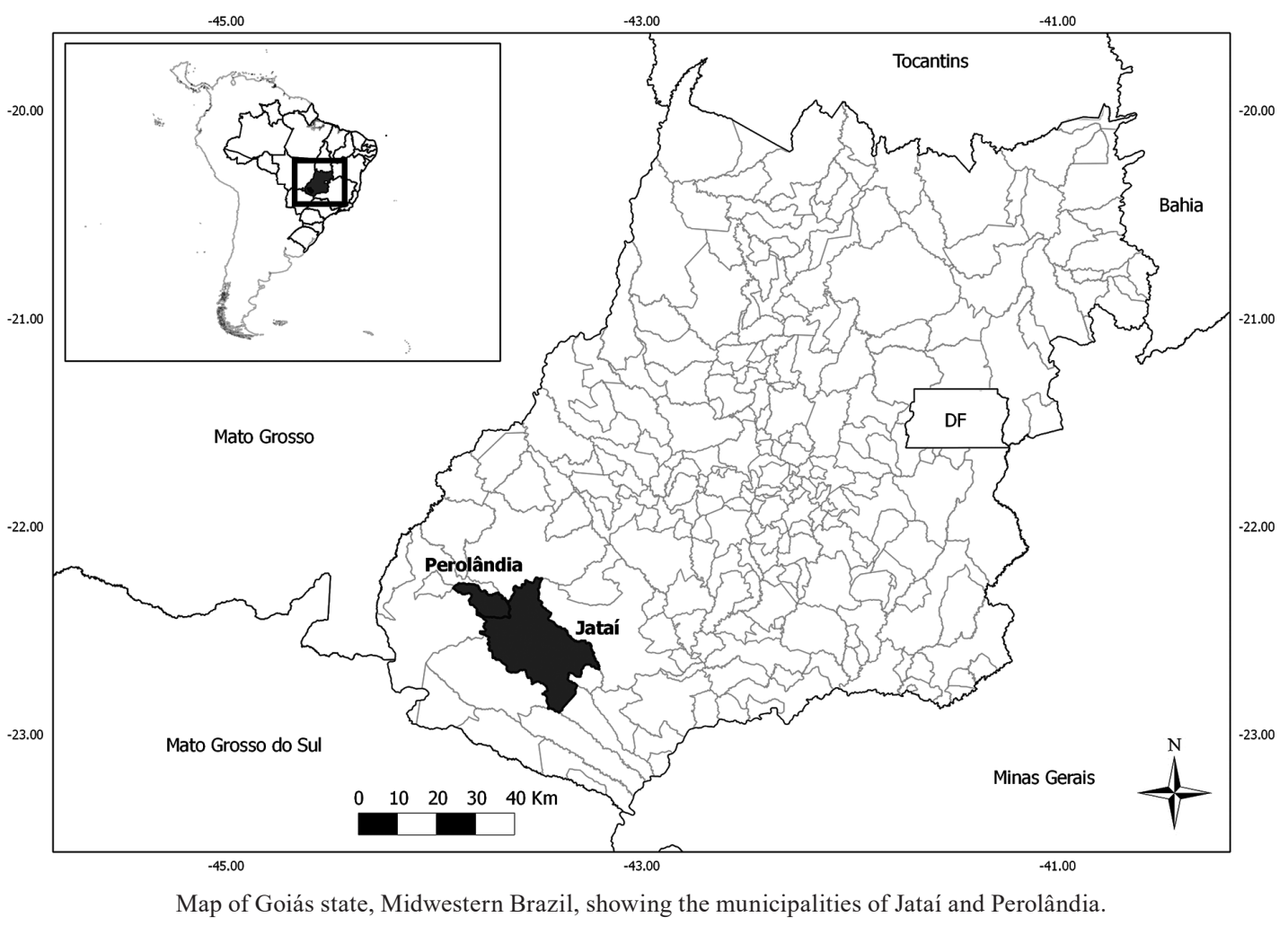

Briefly, 96-round-bottom-well-microplates (Thermo Scientific ${ }^{\mathrm{TM}}$ ) were coated with $100 \mu \mathrm{L}$ of the cell lysate diluted in phosphate-buffered saline (PBS) pH 7.4. One-half of the plate with the infected cell lysate (Junín mammarenavirus strain XJC13 or Maciel orthohantavirus strain \#9) and the other half with the uninfected cell lysate (Vero C76- ATCC ${ }^{\circledR}$ CRL-1587TM). The plates were kept overnight at $4^{\circ} \mathrm{C}$, and then washed five times with $0.1 \%$ Tween 20 (Merck \& Co., Inc., Kenilworth, NJ, USA) in PBS. The wells were then filled with $100 \mu \mathrm{L}$ diluted test sera, starting at 1:100 dilution. As diluent, PBS with $0.1 \%$ Tween 20 (Merck \& Co., Inc., Kenilworth, NJ, USA) and 5.0\% skim milk (BD Difco ${ }^{\mathrm{TM}}$ ) was used. The plates were incubated for $1 \mathrm{~h}$ at $37^{\circ} \mathrm{C}$. After five washes, $100 \mu \mathrm{L}$ of goat Anti-Human IgG peroxidase (Kirkegaard \& Perry Laboratories- KPL, Gaithersburg, MD) conjugated at 1:2000 dilution was placed in each well and the plates were incubated for $1 \mathrm{~h}$ at $37^{\circ} \mathrm{C}$. The five washes were repeated and $100 \mu \mathrm{L}$ of ABTS [2, 2'-azinodi (3-ethylbenzthiazoline-6-sulfonate)] substrate (KPL, Gaithersburg, MD) was added to each well. The plates were kept for $30 \mathrm{~min}$ at $37^{\circ} \mathrm{C}$. Objective reading of ELISA results was performed by determination of absorbencies at 405 and $450 \mathrm{~nm}$. The cut-off was determined by the mean optical densities (OD) of the negative controls plus three standard deviations at 1:100 dilution.

Aiming to test the association among variables, chisquare tests $\left(\chi^{2}\right)$ were used to verify those variables that presented a relationship with the outcome variable (detection of anti-hantavirus IgG antibodies) in order to perform a modeling process. Univariate logistic regression analyses were performed between serology results and those other variables that demonstrated association with the outcome by $\chi^{2}$ analysis with p-value under $30 \%$ and Odds ratios (OR) and $95 \%$ confidence intervals $(95 \% \mathrm{CI})$ were estimated. Data analysis was performed using the statistical package R (version 3.1.1).

Nearly half of the population was male (52.1\%). The median age was 41 years (minimum: 2; maximum: 93), and monthly income of approximately \$210.00 USD (minimum: 39; maximum: 3460, USD, approximately). Most are self-declared mixed race (60.1\%) and had a maximum of nine years of formal schooling $(82.5 \%)$. About $68.0 \%$ of all participants had lived in canvas or improvised plastic tents in provisory settlements (Table).

Of the 466 individuals enrolled in the study, 12 $(2.57 \%)$ were reactive for orthohantavirus and $3(0.64 \%)$ for mammarenavirus. One individual was reactive for both tests, but high titers for orthohantavirus (1:6400) were found. Arenavirus antibodies were found only in Terra e Liberdade settlement (3/141 - 2.1\%) in both sex (two men and one woman) with ages ranging from 16 to 66 years. Although we do not have detailed information on the medical history of these individuals, all of them reported having been hospitalised at some point for not specified clinical (not chirurgical) reasons.

Hantavirus antibodies were present in all seven settlements, with prevalence ranging from $0.9 \%(1 / 101$ - Nossa Senhora de Guadalupe), 1.4\% (2/141 - Terra e Liberdade), 2.0\% (1/47 - Santa Rita), 4.0\% (1/25 - Lagoa do Bonfim), 4.3\% (4/92 - Gurita) and Rio Claro (1/23) to $5.4 \%$ (2/37 - Três Pontes). Six individuals referring to hospitalisation for not specified clinical reasons at some 
TABLE

Distribution of caracteristic, prevalence of seropositivity (detection of anti-hantavirus IgG antibodies) and chi-square test ( $\mathrm{p}$-value) for rural population in Goiás, Brazil

\begin{tabular}{|c|c|c|c|c|}
\hline Variable & N (\%) & Seropositivity (\%) & $\chi^{2}$ p-value & OR $(95 \% \mathrm{CI})$ \\
\hline Age & & & 0.29 & \\
\hline$\leq 18$ & $118(25.3)$ & $1(0.8)$ & & 1 \\
\hline $19-40$ & $110(23.6)$ & $2(1.8)$ & & $2.16(0.19-24.2)$ \\
\hline $41-60$ & $191(41.0)$ & $8(4.2)$ & & $5.11(0.63-41.4)$ \\
\hline$>61$ & $47(10.1)$ & $1(2.1)$ & & $2.54(0.15-41.4)$ \\
\hline Sex & & & 0.88 & \\
\hline Female & $223(47.9)$ & $6(2.7)$ & & \\
\hline Male & $243(52.1)$ & $6(2.5)$ & & \\
\hline Setllement & & & 0.59 & \\
\hline Terra & $141(30.3)$ & $2(1.4)$ & & \\
\hline Guadalupe & $101(21.7)$ & $1(1.0)$ & & \\
\hline Gurita & $92(19.7)$ & $4(4.3)$ & & \\
\hline Santa Rita & $47(10.1)$ & $1(2.1)$ & & \\
\hline Três Pontes & $37(7.9)$ & $2(5.4)$ & & \\
\hline Rio Claro & $23(4.9)$ & $1(4.3)$ & & \\
\hline Lagoa & $25(5.4)$ & $1(4.0)$ & & \\
\hline Monthly income (USD) & & & 0.75 & \\
\hline$\leq 330$ & $325(72.9)$ & $9(2.8)$ & & \\
\hline $331-660$ & $113(25.3)$ & $2(1.8)$ & & \\
\hline$\geq 661$ & $8(1.8)$ & $0(0.0)$ & & \\
\hline School (years) & & & 0.15 & \\
\hline$\leq 4$ & $202(46.3)$ & $8(4.0)$ & & 1 \\
\hline $5-9$ & $170(39.0)$ & $3(1.8)$ & & $0.43(0.10-2.17)$ \\
\hline$\geq 10$ & $64(14.7)$ & $0(0.0)$ & & - \\
\hline Smoke & & & 0.18 & \\
\hline No & $302(75.9)$ & $6(2.0)$ & & 1 \\
\hline Yes & $95(29.9)$ & $5(5.3)$ & & $2.74(0.81-9.19)$ \\
\hline Time living in the settlement (days) & & & 0.09 & \\
\hline$\leq 30$ & $85(18.4)$ & $2(2.4)$ & & 1 \\
\hline $31-60$ & $265(57.5)$ & $4(1.5)$ & & $0.63(0.11-3.53)$ \\
\hline$\geq 61$ & $111(24.1)$ & $6(5.4)$ & & $2.37(0.46-12.05)$ \\
\hline Time living in camps (months) & & & 0.36 & \\
\hline$\leq 50$ & $160(51.3)$ & $4(2.5)$ & & \\
\hline $50-100$ & $116(37.2)$ & $5(4.3)$ & & \\
\hline$\geq 100$ & $36(11.5)$ & $0(0.0)$ & & \\
\hline Garbage & & & 0.49 & \\
\hline Burnt & $267(59.7)$ & $5(1.9)$ & & \\
\hline Buried & $19(4.3)$ & $0(0.0)$ & & \\
\hline Collected & $145(32.4)$ & $5(3.4)$ & & \\
\hline Other & $16(3.6)$ & $1(6.2)$ & & \\
\hline Sanitation & & & 0.47 & \\
\hline No & $100(21.7)$ & $1(1.0)$ & & \\
\hline Yes & $361(78.3)$ & $11(3.0)$ & & \\
\hline
\end{tabular}

point of their lives. There was no statistically significant difference between the evidence of hantavirus infection and the variables showed in Table. Due to low number of mammarenavirus reactive samples, statistical analyses were performed considering only hantavirus reactivity.
Encroachment of human settlements and agriculture on natural ecosystems results in expansion of transition zones between these two ecological systems, where species assemblages from different habitats can mix. ${ }^{(2,12)}$ This provides new opportunities for pathogen spillover, genetic 
diversification, and adaptation. Associations between disease emergence in transition areas have been suggested for several diseases, including yellow fever, HPS, Nipah virus encephalitis, rabies, cholera, leptospirosis. $(7,13,14)$

HPS is considered a rural disease and consequently rural dwellers as well as individuals who are often in contact with the rural area are considered as risk group. Goiás state has 98 confirmed HPS cases, since $2000 .^{(7,8,15)}$ Two hantaviruses have been detected in the state, Araraquara and Juquitiba virus in $N$. lasiurus and $O$. nigripis rodents, respectively. ${ }^{(16)}$ The prevalence of anti-hantavirus IgG antibodies detected in this study is in accordance with prevalence found in different studies conducted in rural populations from Brazil $(0.4 \%$ to $22.0 \%),{ }^{(17,18,19,20,21,22,23)}$ but is lower than the one found for Jataí municipality $3.9 \%$ (95\% CI: 2.3-5.7). . $^{(2)}$ According to Guzmán et al., ${ }^{(1)}$ this difference could be explained by the lower sensitivity found in the serological testes using Maciel orthohantavirus when compared to those obtained using Araraquara orthohantavirus. Studies also show considerable serological prevalence for hantavirus in men, that seem to link hantavirus infection and field related activities. This fact was not observed in our study, probably due to the rudimentary living conditions, especially during their time in improvised camps, where man and woman could be exposed in their habitations during indoors activities, as reported in works conducted in Brazil and Chile. ${ }^{(19,22,25)}$

Mammarenavirus prevalence is variable in different endemic areas. Our results are comparable with ones found in other South American countries. In Argentina, studies demonstrated low prevalence of unapparent infections ranging from $1.93 \%(3 / 155)$ to $4.44 \%(24 / 540)$ for rural populations from Córdoba and Buenos Aires provinces, respectively. ${ }^{(26)}$ The prevalence of Guanarito virus infection among humans from Portuguesa state, Venezuela, was $2.60 \%(5 / 195)$, all adults living in rural areas and two had previously been reported as Venezuelan hemorrhagic fever cases. ${ }^{(27)}$ Machado et al. ${ }^{(28)}$ observed that $1.40 \%(5 / 343)$ individuals living in the municipality of Nova Xavantina (Mato Grosso state, Brazil), who presented fever with unidentified etiology, presented antibody titers against arenavirus. It is important to notice that Argentina and Venezuela are endemic countries for arenavirus hemorrhagic fevers, with several reported cases. Thus, during the emergence of American hemorrhagic fever a scenario of sociodemographic expansion and increased deforestation was described in Argentina and Venezuela, ${ }^{(26,27)}$ the same factors that are present in the studied area.

To date there are few evidences of arenaviruses causing human infections in Brazil; the presence of antibodies in rural population in similar rates to those found in endemic countries points out for a probable silent circulation of mammarenaviruses in rural areas of Brazil. ${ }^{(28,29)}$ The only settlement where serological evidences for arenavirus were found (Terra e Liberdade - Jataí county) is $953 \mathrm{~km}$ of distance from the probable local of infection of the first and only case of Brazilian hemorrhagic fever reported. ${ }^{(9)}$ To date, at least eight mammarenavirus have been described in Brazil, two from Midwestern states.
(30,31) The identification of seroreactivity in just one settlement could represent a local circulation of a distinct mammarenavirus, especially considering the natural nidality attributed to some mammarenaviruses. ${ }^{(32)}$

Until Brazilian government established these settlements between 1998 and 2007, many of the landless rural residents lived in this precarious condition, arranging in canvas or plastic tents, for many years. The long period under unfavorable infrastructure, socioeconomic disadvantages, and unsanitary conditions may represent a risk of acquiring hantavirus and mammarenavirus infections. The intense process of degradation in recent decades, with large areas planted with monoculture crops, can favor generalist rodent species in interspecific competition with other rodents, mostly habitat specialists. The general behavior of many rodent-borne reservoirs as $N$. lasiurus and $O$. nigripes make these species highly adaptable to man-made environments. ${ }^{(16)}$ The ecological pattern of these rodents associated with deep anthropogenic changes areas provide by improvised camps or rural settlements greatly increases the chances of contact between humans and infected rodents, mainly due to the potential increase in population density and the narrowing of environments shared with humans. (2,6,16) $^{(2,6)}$

Rodent-borne infections are highly lethal diseases especially in rural areas, where poor people that depend on the land to survive are constantly exposed to rodents, with low access to medical care. Implementation of public policies towards the improvement of health access, sanitation and awareness of rodent-borne diseases in improvised camps and settlements is needed, in order to prevent human infection and reduce morbidity and mortality caused by these diseases. In the future, sustainable agricultural systems that minimise the risk of emerging disease will therefore be essential to meet the requirements of the rising rural settlers' population, while protecting human health and conserving biodiversity and the environment.

\section{ACKNOWLEDGEMENTS}

To Gabriel Rosa Cavalcanti (Laboratório de Hantaviroses e Rickettsioses, Instituto Oswaldo Cruz, Fiocruz), Ágabo Macedo da Costa e Silva, Gabryella Teixeira dos Santos (Universidade Federal de Goiás - UFG) and Bernardo Teixeira (Instituto Oswaldo Cruz, Fiocruz) for their collaboration and technical support.

\section{AUTHORS' CONTRIBUTION}

JF, RCO, TAC, MAPH and SL performed lab experiments, processed the data; RMBM, KAAC, MASC and SAT conducted field studies; JF, RCO and ERSL draft the manuscript; ERSL and SAT conceived the study and coordinated the resources.

\section{REFERENCES}

1. Vandegrift KJ, Wale N, Epstein JH. An ecological and conservation perspective on advances in the applied virology of zoonoses. Viruses. 2011; 3(4): 379-97.

2. Jones BA, Grace D, Kock R, Alonso S, Rushton J, Said MY, et al. Zoonosis emergence linked to agricultural intensification and environmental change. Proc Natl Acad Sci USA. 2013; 110(21): 8399-404.

3. Wittman H. Reframing agrarian citizenship: land, life and power in Brazil. J Rural Stud. 2009; 25(1): 120-30. 
4. Pinheiro RS, Araújo LA, Caetano KA, Matos MA, Carneiro MA, Teles SA. Intermediate endemicity of hepatitis A virus infection in rural settlement projects of Southwest Goiás, Brazil. Arq Gastroenterol. 2015; 52(3): 200-3.

5. Freitas NR, Teles SA, Caetano KAA, Matos MA, Carneiro MADS, Gardinali NR, et al. Hepatitis E seroprevalence and associated factors in rural settlers in Central Brazil. Rev Soc Bras Med Trop. 2017; 50(5): 675-9.

6. Mota BE, Trindade GS, Diniz TC, da Silva-Nunes M, Braga EM, Urbano-Ferreira M, et al. Seroprevalence of orthopoxvirus in an Amazonian rural village, Acre, Brazil. Arch Virol. 2010; 155(7): 1139-44.

7. de Oliveira RC, Guterres A, Fernandes J, D’Andrea PS, Bonvicino CR, de Lemos ER. Hantavirus reservoirs: current status with an emphasis on data from Brazil. Viruses. 2014; 6(5): 1929-73.

8. Pinto VL, de Sousa AI, de Lemos ER. Regional variations and time trends of hantavirus pulmonary syndrome in Brazil. Epidemiol Infect. 2014; 142(10): 2166-71.

9. Coimbra TLM, Nassar ES, Burattini MN, de Souza LT, Ferreira I, Rocco IM, et al. New arenavirus isolated in Brazil. Lancet. 1994; 343(8894): 391-2.

10. Riera LM, Feuillade MR, Saavedra MC, Ambrosio AM. Evaluation of an enzyme immunosorbent assay for the diagnosis of Argentine haemorrhagic fever. Acta Virol. 1997; 41(6): 305-10.

11. Guzmán C, Mattar S, Levis S, Pini N, Figueiredo T, Mills J, et al. Prevalence of antibody to hantaviruses in humans and rodents in the Caribbean region of Colombia determined using Araraquara and Maciel virus antigens. Mem Inst Oswaldo Cruz. 2013; 108(2): 167-71.

12. Hassell JM, Begon M, Ward MJ, Fèvre EM. Urbanization and disease emergence: dynamics at the Wildlife-Livestock-Human interface. Trends Ecol Evol. 2017; 32(1): 55-67.

13. Despommier D, Ellis BR, Wilcox BA. The role of ecotones in emerging infectious diseases. EcoHealth. 2006; 3(4): 281-9.

14. Pfeffer M, Dobler G. Emergence of zoonotic arboviruses by animal trade and migration. Parasit Vectors. 2010; 3(1): 35.

15. Menezes HR, Moreli ML, Sousa AL, Costa VG. Cross-sectional study on case fatality rate due to hantavirus infection in Goiás state, Brazil, 2007-2013. Epidemiol Serv Saude. 2016; 25(3): 519-30.

16. Guterres A, de Oliveira RC, Fernandes J, Maia RM, Teixeira BR, Oliveira FCG, et al. Co-circulation of Araraquara and Juquitiba Hantavirus in Brazilian Cerrado. Microb Ecol. 2017; 75(3): 783-9.

17. Gimaque JBL, Bastos MS, Braga WSM, de Oliveira CMC, Castilho MC, de Figueiredo RMP, et al. Serological evidence of hantavirus infection in rural and urban regions in the state of Amazonas, Brazil. Mem Inst Oswaldo Cruz. 2012; 107(1): 135-7.

18. Pereira GW, Teixeira AM, Souza MS, Braga AD, Santos Jr GS, Figueiredo GG, et al. Prevalence of serum antibodies to hantavirus in a rural population from the Southern state of Santa Catarina, Brazil. Rev Soc Bras Med Trop. 2012; 45(1): 117-9.

19. Souza WM, Machado AM, Figueiredo LT, Boff E. Serosurvey of hantavirus infection in humans in the border region between Brazil and Argentina. Rev Soc Bras Med Trop. 2011; 44(2): 131-5.
20. Holmes R, Boccanera R, Figueiredo LT, Mançano SR, Pane C. Seroprevalence of human hantavirus infection in the Ribeirão Preto region of São Paulo state, Brazil. Emerg Infect Dis. 2000; 6(5): 560-1.

21. Badra SJ, Maia FG, Figueiredo GG, dos Santos Jr GS, Campos GM, Figueiredo LT, et al. A retrospective serologic survey of hantavirus infections in the county of Cássia dos Coqueiros, state of São Paulo, Brazil. Rev Soc Bras Med Trop. 2012; 45(4): 468-70.

22. Amaral CD, Costa GB, de Souza WM, Alves PA, Borges IA, Tolardo AL, et al. Silent orthohantavirus circulation among humans and small mammals from Central Minas Gerais, Brazil. EcoHealth. 2018; 15(3): 577-89.

23. de Oliveira RC, Guterres A, Teixeira BR, Fernandes J, Penna Jr JM, Oliveira Jr RJ, et al. A fatal hantavirus pulmonary syndrome misdiagnosed as dengue: an investigation into the first reported Case in Rio de Janeiro state, Brazil. Am J Trop Med Hyg. 2017; 97(1): 125-9.

24. Moreli ML, Novaes DPDS, Flor EC, Saivish MV, Costa VGD. Seropositivity diagnosis for hantavirus in Jataí, Goiás state, Brazil. Rev Soc Bras Med Trop. 2017; 50(4): 530-4.

25. Muñoz-Zanzi C, Saavedra F, Otth C, Domancich L, Hott M, Padula P. Serological evidence of hantavirus infection in apparently healthy people from rural and slum communities in southern Chile. Viruses. 2015; 7(4): 2006-13.

26. Weissenbacher MC, Sabattini MS, Avila MM, Sangiorgio PM, de Sensi MR, Contigiani MS, et al. Junin virus activity in two rural populations of the Argentine hemorrhagic fever (AHF) endemic area. J Med Virol. 1983; 12(4): 273-80.

27. Tesh RB, Wilson ML, Salas R, de Manzione NM, Tovar D, Ksiazek TG, et al. Field studies on the epidemiology of Venezuelan hemorrhagic fever: implication of the cotton rat Sigmodon alstoni as the probable rodent reservoir. Am J Trop Med Hyg. 1993; 49(2): 227-35.

28. Machado AM, Figueiredo GG, Campos GM, Lozano ME, Machado AR, Figueiredo LT. Standardization of an ELISA test using a recombinant nucleoprotein from the Junin virus as the antigen and serological screening for arenavirus among the population of Nova Xavantina, state of Mato Grosso. Rev Soc Bras Med Trop. 2010; 43(3): 229-33.

29. Fernandes J, Coelho TA, Oliveira RC, Guterres A, Oliveira EC, Terças ACP, et al. Silent arenavirus infection in individuals living in Colniza, Mato Grosso, Brazil. Rev Soc Bras Med Trop. 2018; 51(6): 881-2.

30. Fernandes J, Guterres A, de Oliveira RC, Chamberlain J, Lewandowski K, Teixeira BR, et al. Xapuri virus, a novel mammarenavirus: natural reassortment and increased diversity between New World viruses. Emerg Microbes Infect. 2018; 7(1): 120.

31. Fernandes J, de Oliveira RC, Guterres A, Serra FC, Bonvicino CR, D'Andrea OS, et al. Co-circulation of Clade $\mathrm{C}$ new world arenaviruses: new geographic distribution and host species. Infect Genet Evol. 2015; 33: 242-5.

32. Salazar-Bravo J, Dragoo JW, Bowen MD, Peters CJ, Ksiazek TG, Yates TL. Natural nidality in Bolivian hemorrhagic fever and the systematics of the reservoir species. Infect Genet Evol. 2002; 1(3): 191-9 